\title{
韓国蔚山地域の農村集落における祭祀空間の構成に関する研究 \\ A STUDY ON THE CONSTITUTION OF THE PLACES FOR RITUALS IN RURAL VILLAGES LOCATED IN ULSAN, KOREA
}

\author{
姜 恵 京*, 西 村一朗**, 韓 三 建*** \\ Hyekyung KANG, Ichiro NISHIMURA and Samgeon HAN
}

\begin{abstract}
This is a research study about the location of special places for rituals in villages in Ulsan, Korea.

Upon resarching 289 villages in Ulsan, Korea, we have found that 88 percent of these villages have two or more special sites for rituals. The primary category types for rituals can be characterized as "Dangmok" and "Jedang". We have found a total of six types of places for rituals.

The most popular ritual sites in Ulsan, Korea are either those exhibiting only a. "Danginok" style, or, those exhibiting both a "Dangmok" style and a "Jedang" style. There are no places for rituals in some villages, such as Won. village and in some commercial villages. These villages were unquie cases from long ago.

In cases where places for $r$ ituals have disappeared altogether incommunities we have found that the cause was a lack of understanging about the historical significance of these ritual sites.
\end{abstract}

keywords : the places for rituals, Ulsan, Dangmok, Jedang 祭祀空間、蔚山、堂木、祭堂

\section{1. 研究の背景と目的}

韓国の伝統的な住居集落は今世紀に人って外部的な要因と内部的 な要因によって大きく変化し始めた。まず,今世紀初頭の植民地支 配による異文化の影響によって大々的な変容を重ねた上,さらに朝 鮮動乱によって壊减的な被害を受けた。このことは建物や施設の被 害のみならず, 韓国国民の生活全般にわたって大きな变容を及ぼし た。特にこれらの外部的な要因によって都市社会及び都市における 住居集落は大きく変わり,伝統的なコミュニティや人間関俰は崩壊し てきた。

しかし, 同様の変化や被害を受けながらも農村部は都市部に比べ ればその変化の程度は相対的に軽く,韓国の伝統的なものが色強く 残されてきた。特に農村部における住居集落では共同性の高い生活 を維持している。その中でも集落の平和と安全及び豊作のために行 われた祭祀 ${ }^{13}$ は集落にある種の秩序を与えてきたものである。これ は集落という地域共同体が儀式信仰の基本単位になることに伴って, 集落民の参加意識を強くしている。

また, 祭祀 (洞祭) だけではなく,洞祭を行う前後に集落会議及び 農楽 ${ }^{2)}$ などを行うことで, 集落住民同士の親睦を深めたり; 結束感を
与える機能をも持っていた。このような性格をもつ洞祭が行われる 祭礼空間は、集落の重要なヨミュニティ空間として存在しながら集 落住民同士の求心的な役割を果たす韓国集落の一つの特徵的な存在 と言えよう。

このような集落の祭祀及び祭祀空間を対象とする調查は植民地時 代の日本人学者によって始められ ${ }^{3}$, 人類学, 社会学, 建築学などの 各分野で続けられている。しかし，これらの研究の視点は祭祀の儀 式そのものに留まっており,祭祀空間である祭堂及び堂木 ${ }^{4)}$ に関す る研究はあまり見当たらない。また，研究対象を 1 力所の集落に限 定して行ったものが多いため,集落での祭祀空間の全体的な傾向が つかみにくい。

そこで,本研究では集落の重要な空間要素として存在してきた祭 祀空閒の構成を考察するため,このような祭祀空閒が多く存在して いる韓国・蔚山（ウルサン）地域の伝統的な農村集落をとりあげ調 查研究を行った。特にこの地域は朝鮮動乱の直接的な被害を受けて いないため、集落の物理的構造や形態はもちろん、住民の構成など にも変化が少なく、本研究に最も適した地域と判断できる。本論文 では, 集落住民の生活と関連して発生し,伝統的に継承してきた祭祀

* 奈良女子大学人間文化研究科 大学院生・家修

** 奈良女子大学生活環境学部 教授. 工博

*** 蔚山大学建築学部 助教授・工博
Graduate Division of Human Culture, Nara Women's Univ., H. Home Eco. Prof., Division of Human Environment, Nara Women's Univ., Dr. Eng. Assistant Prof., School of Architecture, University of Ulsan, Dr. Eng. 
空間の形態や構成を明らかにすることを目的とする。それによって 歷史的環境や地域文化に調和した集落空間構成の特性を明らかにす るのに寄与できるものと判断する。

\section{2. 調査の概要}

本研究では祭祀空間の構成を明らかにするために祭祀空間に関す る文献調查 ${ }^{5)}$ と実態調查を行った。文献調查によって祭祀空間が全 国の集落に存在していることが分かった。それで，祭祀空間が集落 の共同空間として活発に機能している地域の1つを選び, 実態調査 を行った。

（1）調查対象地域および範囲：本研究の調查対象地域の範囲は “郡”という行政区域 ${ }^{6}$ にした。韓国で郡は一つの地域コミュニテ ィとしての生活領域であり, 郡は生活及び風習の境界線ともいえる。 このような一つのまとまった地域性をもつ郡に属するすべての集落 を調查することによって集落の祭祀空間の全体的な傾向をつかむこ とが可能になる。そういうわけで一つの郡を調查対象範囲とし, 慶 尚南道の蔚山郡を選び，調查を行った）（図 1)。

蔚山郡は蔚山市を取り囲む地域で都市開発の波からも逃れ伝統的 な集落の形を維持している所である。蔚山郡には 14 の行政単位 （邑 3,面 11 ）に325 カ所の集落がある。今回の調查ではその 内 1990 年以降に新しく開発され集合住宅団地となった 36 力所 を除き,伝統性を有する 289 力所の集落を調查対象地域とした。

(2) 調查概要 : まず予備調查では、各村の里長を対象としたア ンケート調查と文献調查を行い、祭祀空間の有無を調へた。調查対 象集落 289 力所の内、254 力所の集落に祭祀空間の存在が確認 できた（図2）。1995年8月から19 98 年 1 月までの本調查では、祭祀空間が 存在している集落に対して、祭祀空間の構 成要素、構造、規模などを実測し、立地的 要素を調查した。一方、祭祀空間が存在し ていない集落に対してはその理由を探り明 らかにした。

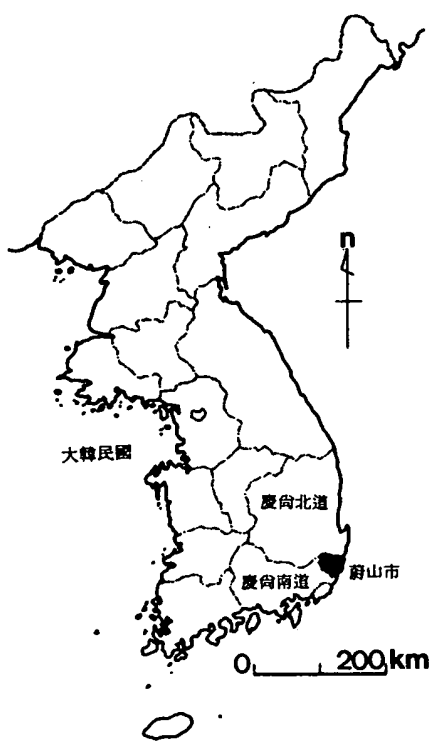

図 1 調查地域の位㯰

\section{3. 祭祀空間の概要}

(1) 祭祀空間の定義

1 ) 祭祀とは神々や祖先などをまつる儀式であり、それを行う 場所が祭祀空間である。集落の祭祀である洞祭を行う空間を集落の 祭祀空間と定義する。

2) 集落には一つ,または二つ以上の祭祀空間が設けられてい る。それは普通、木造建物と大きな木で搆成されている。木は、ダ ンスナム (堂木) ${ }^{8)}$ と呼ばれている生きた樹木とザンスン (長生) 9) と呼ばれている木の䧓刻に分けられる。建物はゼダン (祭堂) 10) と呼ばれている主屋と附属舎に分けられる。また,これ以外にも 祭祀空間の構成要素として岩または石皘みがある。

(2) 祭祀空間の分類

祭祀空間は,一つまたは一つ以上の構成要素の組み合わせでそれ ぞれ構成され，表 1 のように 6 つのタイプに分類できる。

(3) 祭祀空間の構成要素

1) 堂木 (ダンスナム)

一般的に堂木は、樹齢の古い老巨樹で構成された集落のシンボル 的な存在である。集落の祭祀の対象となることから神木と呼ばれる 場合もある。樹木の中でケヤキ,エノキ, 銀杏が三大神木であり,こ れらは葉の形から農事の豊凶を見る農業気象木でもある。調查地域 では16 種類の堂木が 232 集落, 266 力所 ${ }^{11)}$ で堂木数の多い順 にケヤキ,松, エノキ,アカシデ,エンジュ, 銀杏のように分布してい る。これらは一本または数本で構成されている（表 1、2）。

2) 長生 (ザンスン) (図 3)

長生は柱のような木または石に人の顔を㰹刻したものであり,集

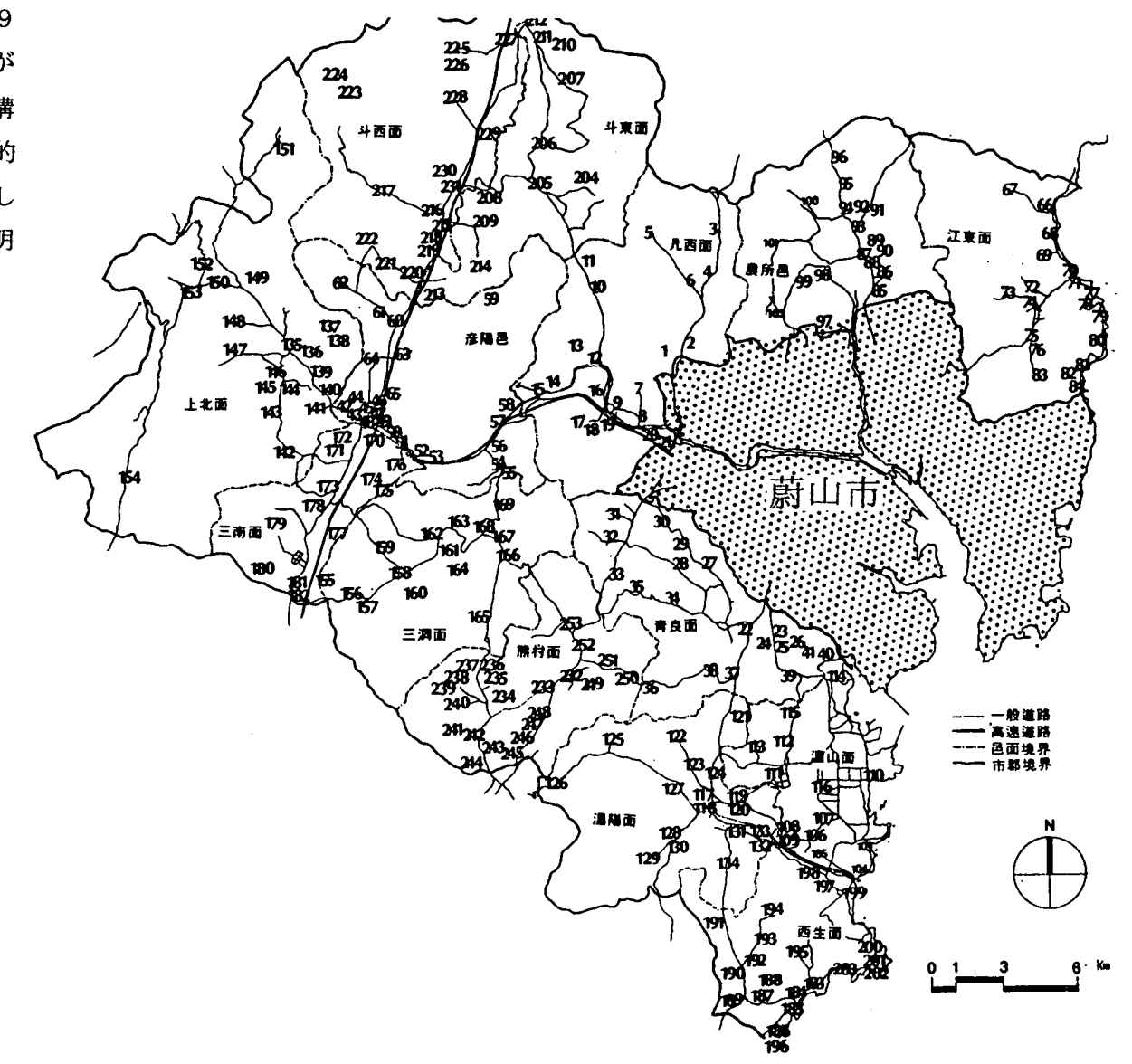


落の入口にたてられ集落間の境界を示すことが多い。調查地域では 5 集落において長生が祭祀空間として存在している。その方向は東 向が 4 例, 南向が 1 例である。

3) 祭堂 (ゼダン) (図 4)

祭堂は 1 間 $\times 1$ 間を基本単位として瓦屋根, 土壁, 木製の屝で構成 されたのが伝統的様式であり、普遍的なものであった。しかし, 現 在は地域, 建立時期, 集落の財政状況などにより,材料, 形態の違いが みられる。調查地域では 1830 集落に2090祭堂がある。まず, 祭堂の向きをると, 南向が最も多く, 次は南東向, 東向, 南西向の 順となっている(表 2)。このように南向きが多いのは，祭堂の方 向が集落の民家の方向と同じものが多いためであると考えられる。 つまり,集落が南側の斜面に南を向いて位置することが多いため, 祭 堂も同じ向きになることが多い。他の集落では違う向きもあらわれ るが，南方向を含むのが殆どである。

祭堂の構造としては木構造, 組積造, R.C.造がある。祭堂の中で 最も多くみられる組積造は 132 例の内, ブロック造が 115 例, レ ンガ造 8 例, 石造 9 例である。木構造は 71 例がみられるが, これ

\section{表 1 祭祀空間の分類}

\begin{tabular}{|c|c|c|c|c|c|c|}
\hline & I 型 & I 型 & III型 & IV 型 & V 型 & 'VI型 \\
\hline 堂木 & 0 & 0 & & 0 & 0 & \\
\hline 堂木群 & 0 & 0 & & 0 & 0 & \\
\hline 祭堂 & & 0 & 0 & 0 & & \\
\hline 附屬舍 & & & & 0 & 0 & \\
\hline その他 & & & & & & 0 \\
\hline
\end{tabular}

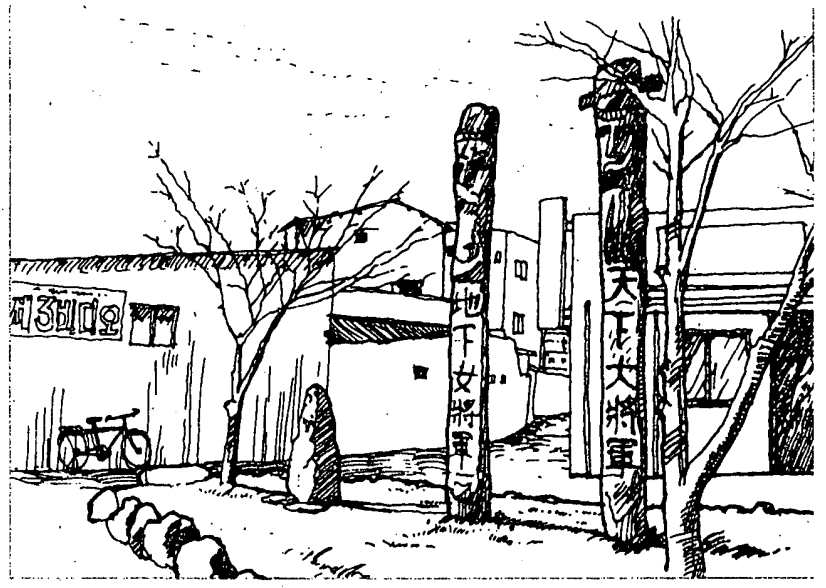

図 3 ザンスンのスケッチ (彦陽邑東部里集落)

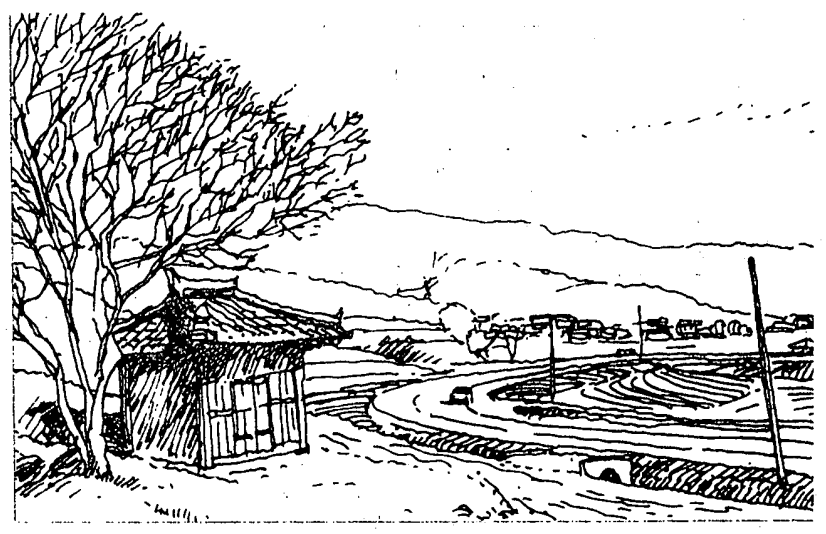

図 4 祭堂のスケッチ (青良面盤亭里集落)
は古いタイプであることから建て替えの度にその数が减っていく傾

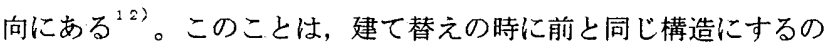
ではなく，その時期に一般的に建てられている構造を取り入れる傾 向を示し、興味深い。このような現象は構造だけではなく，材料に も同じことがみられる(表 3)。

祭堂の屋根は瓦の奇棟形式が最も多くみられる。セメント, 石な どが主な材料である祭堂の屋根の場合はフラットがほとんどである。 壁の材料はコンクリートブロック, 土壁, レンガなどである。祭堂の

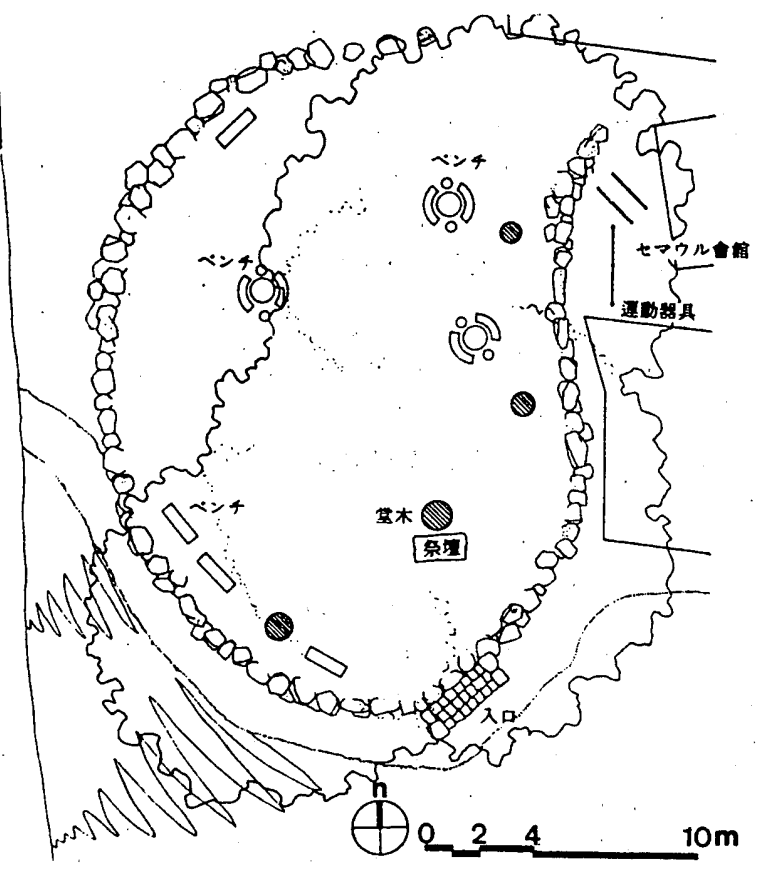

図 5 I 型祭祀空閒 (三同面上鹊集落)

表 2 祭祀空間の構成要素

\begin{tabular}{|c|c|c|c|c|c|c|c|}
\hline & I 型 & 【型 & 而型 & IV型 & V型 & VI型 \\
\hline & & 66事例 & 183事例 & 18事例 & 8事例 & 3事例 & 10事例* \\
\hline \multirow{7}{*}{$\begin{array}{l}\text { 堂 } \\
\text { 木. }\end{array}$} & 松 & 12 & 63 & & 6 & & \\
\hline & ケヤキ & 30 & 73 & & & & $6 *$ \\
\hline & エノキ & 17 & 24 & & 1 & 3 & \\
\hline & その他 & 7 & 23 & & 1 & & \\
\hline & 1 & 60 & 120 & & 7 & 2 & $1 *$ \\
\hline & 2 & 2 & 21 & & & & $4 *$ \\
\hline & 3 & 1 & 4 & & & 1 & 0 \\
\hline & 多 & 3 & 38 & & 1 & & $1 *$ \\
\hline \multirow{8}{*}{$\begin{array}{c}\text { 祭堂 } \\
の \\
\text { 向き }\end{array}$} & 東 & & 16 & 3 & 2 & & $4 * *$ \\
\hline & 西 & & 13 & 1 & & & \\
\hline & 南 & & 82 & 10 & 6 & & $1 * *$ \\
\hline & 北 & & 10 & 1 & & & \\
\hline & 南東 & & 32 & 2 & & & \\
\hline & 北東 & & 7 & 1 & & & \\
\hline & 北西 & & 5 & & . & & \\
\hline & 南西 & & 18 & & & & \\
\hline \multirow{2}{*}{$\begin{array}{l}\text { 榐の } \\
\text { 有無 }\end{array}$} & 有 & 2 & 79 & 10 & 5 & 2 & 0 \\
\hline & 無 & 64 & 104 & 8 & 3 & 1 & 10 \\
\hline \multirow{2}{*}{$\begin{array}{c}\text { Uろばの } \\
\text { 有無 }\end{array}$} & 有 & 44 & 114 & 5 & 6 & 3 & 8 \\
\hline & 無 & 22 & 69 & 13 & 2 & 0 & 2 \\
\hline \multirow{2}{*}{$\begin{array}{c}\text { 大門の } \\
\text { 有無 } \\
\text { (門匪) }\end{array}$} & 有 & 0 & 42 & 2 & 3. & 2 & 2 \\
\hline & 無 & 66 & 141 & 16 & 5 & 1 & 8 \\
\hline
\end{tabular}

* 長生,石積,岩でできた祭祀空間.この內の6例には堂木も存在する.

**長生の向きである 
門屝は木造,形式は両開きが多い。また, 3 例だけであるが,引き戸 もみられる。祭堂を囲む塀は 94 の祭堂でコンクリートブロック, 石でできたものがみられる。そして，その塀に門 ${ }^{13)}$ が設けられてい るのは 52 例あり、材料は鉄, トタン,木,アルミなどとなっている。

以上のように祭堂は, 材料, 形式などが異なるが，行政単位である 面ごと ${ }^{14)}$ の違いはそれほどみられない（表 3)。このことから祭 堂忚地域的に決まった形式があるのではなく, 集落の事情及び時代 の変化により変わっていくものであることが分かる。

4) 附属舎

附属舎は祭祀用の食器などを保管したり，供えものの調理をする 機能を持つ建物である。附属舎を持っている祭祀空間は 11 例であ り, 邑・面別には温山邑, 西生面, 斗東面, 斗西面にそれぞれ $2,6,1$, 2 例がみられる。この 11 例を除いた集落では祭祀の準備または収 納はセマウル会館, 有司の家などを利用している ${ }^{15)} 。$

5 ）岩または石積み

石積みで構成されている 祭祀空間の名称はソナンダンであるが 16) 調查地域ではソナムスプ (アカシデの森) とよばれていた。ま た海岸に面している大きい岩が祭祀空間として機能する例も 1 例み られた。

\section{4.祭祀空間の構成要素から見た集落の特徵}

(1) 祭祀空間の類型別特徵 (表 2 )

分類 I 型は全体の $23 \%, 66$ 例がみられた。その内, 堂木一本で 構成されたものが大半で 60 例がみられた。堂木が立地しているま わりに塀が設けられているのは 2 例だけであり，それ以外に注開放 的に使われていた。また,その中で広場もいっしょに存在するもの
が 44 例みられた。

分類 I型は $63 \%, 183$ 例があり,この地域では最も一般的な夕 イプである。しかし,この調查結果と先行調查の結果 ${ }^{17}$ とには違い がみられた。先行調查で，蔚山地域が属している慶南には分類 П 型 は一つも存在しないと報告されている。しかし蔚山地域だけでも 1 83 例がみられることからその調查結果に問題があることがわかっ た。もちろん, 調查の時期が 1969 年であり,蔚山地域で確認でき た 183 例はそれ以降に建てられたことも考えられるが, 本研究の 聞き取り調查からそのようなことはないことがわかった。

これら 1.83 例の祭堂の中,回りに広場をもうけ,住民の集まりな どに使われているのは 114 例がみられた。また, 祭堂を囲む塀が あるのは 79 例, 大門があるのは 42 例である。

分類而型は $7 \%, 18$ 例がある。その内, 塀があるのが 10 例, 大 門もあるのが 2 例であり，5例が広場を設けている。堂木がなく，祭 堂のみになっているこのタイプの発生背景をみると次の二つが考え られる。まず,堂木はあったものの,それが枯れてしまった場合と祭 堂を新しいところに新筑するときに建物だけを建てて堂木は移植し なかったことである。

分類 IN型は $2 \%, 8$ 例がある。II 型に附属舎があるこのタイプに は塀があるのが 5 例, 大門があるのが 3 例, 広場があるのが 6 例であ る。

分類 $\mathrm{V}$ 型は $1 \%, 3$ 例がある。その中, 2 例が塀と大門がある。広 場は 3 例ともにある。

分類VI型は堂木, 祭堂以外のものが祭祀空間として機能するもの で, 長生, 石積み, 岩などで構成され，全体の $4 \%, 10$ 例がある。そ の内に長生が 5 例あり, 堂木もいっしょにある。向きは東向 4 例, 南

\section{表 3 調查地域別祭堂の構造}

\begin{tabular}{|c|c|c|c|c|c|c|c|c|c|c|c|c|c|c|c|c|c|}
\hline & & & 凡西面 & 清良面 & 彦陽邑 & 江東面 & 罯所邑 & 盜山邑 & 溫陽面 & 上北面 & 三同面 & 三南面 & 西生面 & 斗東面 & 斗西面 & 熊村面 & 鼓 \\
\hline \multirow{5}{*}{ 構造 } & \multirow{3}{*}{$\begin{array}{c}\text { 組䁲 } \\
\text { 造 }\end{array}$} & プロック & 12 & 9 & 12 & 8 & 11 & 10 & 10 & 13 & 1 & 5 & 10 & 3 & 3 & 8 & 115 \\
\hline & & レンガ & & 1 & & 2 & & 1 & & & & 1 & 1 & & & 2 & 8 \\
\hline & & 石 & & & & & & & & 2 & & & 6 & & & 1 & 9 \\
\hline & & 木造 & 5 & 9 & 6 & 7 & 10 & 2 & 12 & 1 & 3 & 2 & 3 & & & 11 & 71 \\
\hline & & R.C 造 & & & & 3 & & 1 & & 1 & & & & & & 1 & 6 \\
\hline \multirow{9}{*}{ 剭根 } & \multirow{5}{*}{ 材料 } & 瓦 & 14 & 16 & 9 & 12 & 14 & 9 & 16 & 5 & 3 & 4 & 15 & 1 & & 17 & 135 \\
\hline & & 本瓦 & & 2 & 4 & 4 & 1 & 2 & 1 & 2 & & 1 & 2 & & & 4 & 23 \\
\hline & & スレート & 1 & & 5 & 1 & & 1 & 2 & 2 & 1 & 1 & 1 & 2 & 1 & 1 & 19 \\
\hline & & コンクリート & 2 & 1 & & 3 & 6 & 2 & 3 & 8 & & 2 & & & 2 & 1 & 30 \\
\hline & & 石 & & & & & & & & & & & 2 & & & & 2 \\
\hline & \multirow{4}{*}{ 型式 } & 入母屋 & 1 & 3 & 2 & 2 & 1 & 3 & 3 & 1 & & 1 & 10 & & & 1 & 28 \\
\hline & & 奇埬 & 9 & 14 & 7 & 5 & 11 & 6 & 14 & 3 & & 3 & 10 & 1 & & 16 & 99 \\
\hline & & 切嘍 & 5 & 1 & 9 & 10 & 3 & 3 & 2 & 6 & 3 & 2 & & 1 & 1 & 5 & 51 \\
\hline & & その他 & 2 & 1 & & 3 & 6 & 2 & 3 & 7 & 1 & 2 & 0 & 1 & 2 & 1 & 31 \\
\hline \multirow{5}{*}{ 壁 } & & 土壁 & 4 & 8 & 4 & 7 & 8 & 2 & 10 & 1 & 3 & 2 & 1 & & & 11 & 61 \\
\hline & コン & クリートプロック & 12 & 9 & 13 & 11 & 13 & 10 & 12 & 13 & 1 & 5 & 10 & 3 & 3 & 9 & 124 \\
\hline & & レンガ & & 1 & & 2 & & 2 & & 1 & & 1 & 3 & & & 2 & 12 \\
\hline & & 石 & 1 & & & & & & & 2 & & & 6 & & & 1 & 10 \\
\hline & & その他 & & 1 & 1 & & & & & & & & & & & & 2 \\
\hline \multirow{6}{*}{ 門屝 } & \multirow{4}{*}{ 材料 } & 木 & 5 & 14 & 9 & 5 & 10 & 7 & 8 & 2 & 3 & - & 6 & 1 & & 15 & 85 \\
\hline & & アルミ & 4 & 3 & 1 & 4 & 3 & 5 & 3 & & & 3 & 4 & & & 4 & 34 \\
\hline & & トタン & 8 & 1 & 6 & 10 & 7 & 2 & 11 & 13 & 1 & 2 & 9 & 2 & 3 & 3 & 78 \\
\hline & & 鐵 & & 1 & 2 & 1 & 1 & & & 2 & & 3 & 1 & & & 1 & 12 \\
\hline & \multirow{2}{*}{ 型式 } & 雨開き & 5 & 14 & 13 & 12 & $6 * *$ & 8 & 17 & 8 & 3 & 6 & 17 & 1 & & 19 & 129 \\
\hline & & 片開き & 12 & 5 & 5 & 8 & 14 & $4 *$ & 5 & 9 & 1 & 2 & 3 & 2 & 3 & 4 & 77 \\
\hline \multirow{2}{*}{ 辡 } & \multicolumn{2}{|c|}{ コンクリートプロック } & 3 & 8 & 3 & 15 & 12 & 7 & 10 & & & 1 & 10 & & & 6 & 75 \\
\hline & & 石 & 3 & 2 & 4 & 1 & 1 & & 1 & 2 & 2 & & 1 & & & 2 & 19 \\
\hline \multirow{4}{*}{ 大門 } & & 鐵 & 4 & 4 & 3 & 5 & 4 & 2 & 4 & & & 1 & 5 & & 4 & 1 & 37 \\
\hline & & フルミ & & & & & & 1 & & & & & 1 & & & & 2 \\
\hline & & 木 & 1 & 3 & & & & & & & & & & & & 1 & 5 \\
\hline & & トタン & & & 4 & & 4 & & & & & & & & & & 8 \\
\hline
\end{tabular}

* 引き戶 2 例は、表の數值には含まれていない

** 引き户 1 例は、表の數値には含まれていない 
向 1 例であり、広場を持っている。石積みでできている祭祀空間は 2 例あり，その内 1 例は堂木まいっしょにある。海辺の岩が祭祀空 間になっているのが 1 例ある。また, 碑石が祭祀空間になっている 例も一つあるが：、独堂木が枯れた跡に立てたものである。そに て, 決まった場所がなく, 毎年違う場所（山,野原, 集落の広場など）

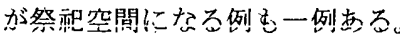

以上のように祭祀空間は 6 つのタイブに大別できるが，この調査 地域では主に祭堂と堂木で構成されているのが最も一般的であるこ とが分かった。

（2）祭祀空間の類型と主な分布地域

祭祀空間の構成要素による類型を調杳地域別にみると，I 型は三 同面，斗東面，斗西面に多く分布している。この3つの地域は都市か ら離れた場所であり，農村と山村が共存する地域的特徵をもってい る。祭祀空間の原型が樹木（神木）であること ${ }^{18)}$ からすると,都市 化が進んでいないこの地域では，祭祀空間の変化も少ないと考えら れる。とりわけ, 堂木のまわりに祭堂や附属舎を造るような祭祀空 間の変化がこの地域ではあまり見あたらない。

II型は江東面, 熊村面, 農所邑に多く分布している。この地域は都 市近郊農村と都市近郊漁村地域である。都市近郊地域の集落は他の 地域より都市化が進む一方, 変化も多い。祭祀空間の変化も同じで あり，I型より新しいタイプのா型がこの地域のほとんどの集落に 分布している.また，この地域では建て替えも活発に行われ祭祀空 間に多くの变化が見られる（このことについては別稿で論じる）。

III型は温陽面，西生面に主にみられるが，この地域はI型も多く 見られているため, 地域的な特徵はない。只，この二つの地域は隣 接しており祭祀空間の形などが類似していることが指摘できる.

IV型，V型，V型は地域別の分布の差はみられない。

以上のように各邑・面の地域的特徴と集落の祭祀空間の類型との 関係について考察したが，主にI，II型でその差がみられた。この ことは祭祀空間の構成が I， II 型が殆どであることと一致する.

\section{5. 祭祀空間の有無之集落の特性}

(1) 祭祀空間の有無

調查地域の 289 力所の集落の中，254 カ所の集落に祭祀空間 表 4 地域別の集落数及び分類別祭祀空間数

\begin{tabular}{|c|c|c|c|c|c|c|c|c|c|}
\hline \multirow{2}{*}{$\begin{array}{l}\text { 闠杪 } \\
\text { 地域 }\end{array}$} & \multirow{2}{*}{$\begin{array}{l}\text { 全休 } \\
\text { 集洺数 }\end{array}$} & \multirow{2}{*}{$\begin{array}{c}\text { 祭祀空間 } \\
\text { がある集 } \\
\text { 落数 }\end{array}$} & \multicolumn{7}{|c|}{ 種類別祭祀空間数 } \\
\hline & & & $\mathrm{I}$ 型 & 【型 & 四型 & IV型 & $\mathrm{V}$ 型 & VI型 & 計 \\
\hline 凡西面 & 25 & 21 & $\overline{4}$ & 17 & & & & & 21. \\
\hline 营良面 & 27 & 20 & 2 & 15 . & 4 & & & & 21 \\
\hline 颜陽面 & 26 & 24 & 6 & 18 & & & & 5 & 29 \\
\hline 江束颛 & 19 & 19 & & 19 & 1 & & & 2 & 22 \\
\hline 崐所总 & 20 & 18 & & 20 & 1 & & & & 21 \\
\hline 溫圠邑 & 15 & 14 & 2 & 12 & 0 & 2 & & 1 & 17 \\
\hline 滥陽而 & 21 & 18 & & 16 & 6 & & & & 22 \\
\hline E北俑 & 20 & 20 & 10 & 17 & & & & 1 & 28 \\
\hline 三同面 & 15 & 15 & 14 & 4 & & & & & 18 \\
\hline 三消面面 & 22 & 13 & 6 & 8 & & & & & 14 \\
\hline 西生面 & 22 & 21 & 1 & 10 & 4 & 6 & & & 21 \\
\hline 斗束而 & 18 & 11 & 8 & 3 & & & 1 & & 12 \\
\hline *四面们 & 17 & 17 & 13 & 3 & & & 2 & & 18 \\
\hline 熊村面ii & 22 & 22 & & 21 & 2 & & & 1 & 24 \\
\hline 㖕 & 289 & 254 & $\begin{array}{c}66 \\
\text { (23) }\end{array}$ & $\begin{array}{l}183 \\
(63)\end{array}$ & $\begin{array}{l}18 \\
(7)\end{array}$ & $\begin{array}{c}8 \\
(2)\end{array}$ & $\begin{array}{c}3 \\
(1)\end{array}$ & $\begin{array}{l}10 \\
(4)\end{array}$ & $\begin{array}{c}288 \\
(100)\end{array}$ \\
\hline
\end{tabular}

*( )の中の数字は\%
が存在し，集落の祭祀空間の存在比率は $88 \%$ ある。祭祀空間に ついて初めて調查が行われた 1936 年の朝鮮総督府の調查記録を 見ると、当時この地域の集落に対する祭祀空間の存在比率は $70 \%$ であったそのことから見ると時代が下がることに上って祭祀空間 增加を示していることがわかる ${ }^{19 !}$ 。

集落に沽ける祭㜔空間の数をみると 288 力所であり，これ任集 落の数を上回っている（表 4)。このことは一つの集落に必ずしも 一つの祭祀空間が存在するものではないことを示している。これは 二つの原因によるものと考えられる。まず第 1 に，規模が大きい集 落 $^{20)}$ にはそれぞれ通称上堂, 下堂と呼ばれる祭堂が二つ存在す $ろ^{21)}$ 。この場合，上掌は集落の小丘または東山に位置し，下掌は 集落の入口または耕作地近辺に位置していることが多い。第 2 の原 因として考えられるのは，集落の行政区域改編である。その改編で 割合規模が小さい集落幾つかを一つの集落にしたことである。この 行政区域改編は植民地時代である1914 年に全国的規模で行われ， 現在に至っている。このことが祭祀空間の数に変化をもたらしたも

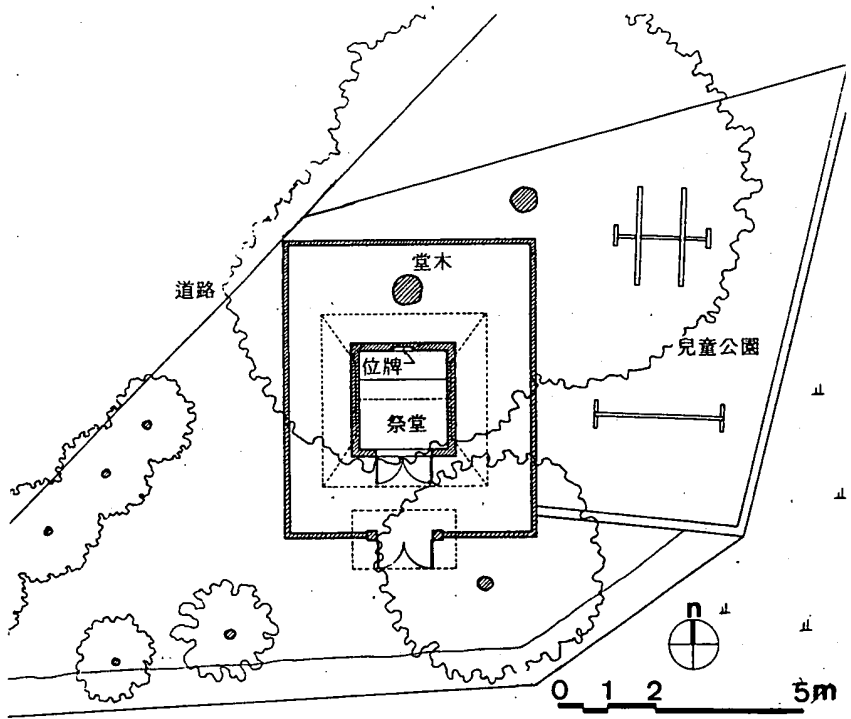

図6 II 型祭祀空間"(熊村面五福集落)

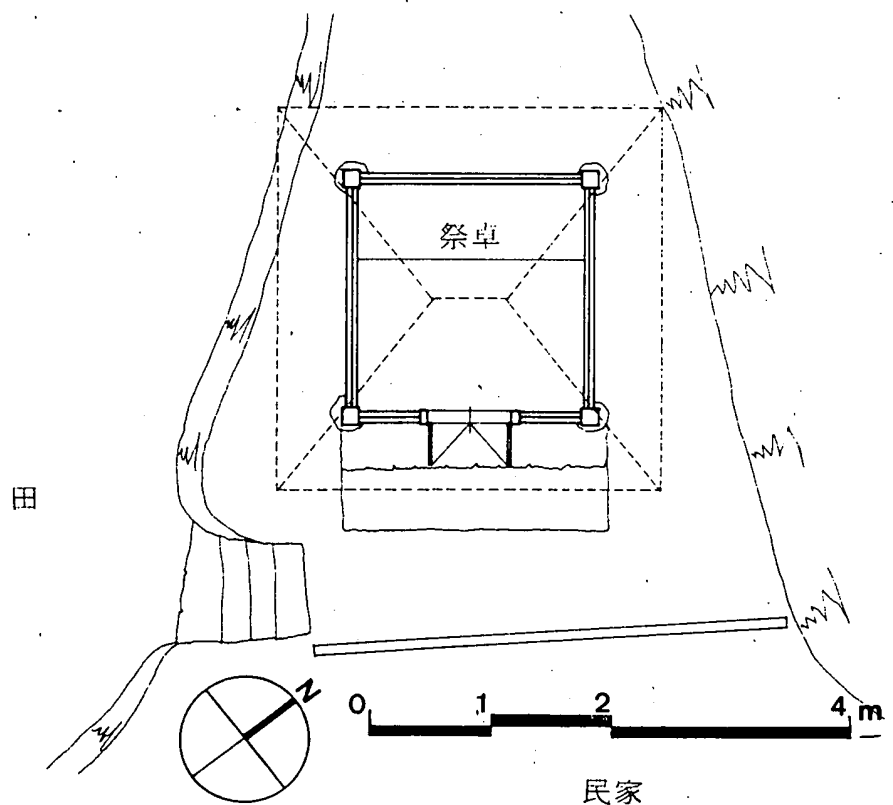

図 7 III型祭祀空間（温陽面東上里下西集楁） 
のと推測できる。

以上の二つの理由から見ると.この調查地域では第二の原因に上 って集落に一つ以上の祭祀空間が存在するようになったと思われる。 その理由としては二つがあげられる。まずこの地域で，一つの集落 に二つの祭堂がある場合の祭堂に対する呼び方をみると，上堂また は下堂という概念はないことが分かった。もう一つは，集落の単位 であって，行政区域名としても住民の認識としても同じ集落であり ながらも，集落の内に一つ以上の別の集落名が存在して混用されて いることである。祭祀空間が二つある 23 力所の集落には二つの集 落名が, 三つある 4 力所の集落には三つの集落名が，四つある 1 カ 所の集落には四つの集落名が存在し使われていたのである ${ }^{22)}$ 。し かし，二つ以上の祭苚空間があり，集落名も二つ以上使われている 集落の場合も祭祀空間での祭り、または日常的な利用については区 別しない。このことから集落名や祭祀空閒が二つ以上ある場合でも 住民は同じ集落として喼識していることが分かる。

調査地域で祭祀空間が現在存在しない集落は全体 289 力所の集 落のうち 35 力所である。この内, 集落の発生時から祭祀空間が全 くなかった集落が 19 力所, 元々は祭祀空間があったが近年になっ てなくなった集落が 16 力所あった。この 35 力所の集落に祭祀空 間が存在しない理由を明らかにした結果，集落の性格の違いが原因 と考えられる。

1）祭祀空間の存在しない集落

集落の発生時から今日に至るまで祭祀空間がまったく存在しなか った集落はその性格によって原因を探ることができた。祭祀空間が ない調査集落を見ると院集落（官営宿泊施設として形成された集 落） ${ }^{23)}$ ，市場として形成された集落, 新しく開発された集落に大 きく分けられる。これらの集落の性格が祭祀空間の存在に影響を及 ぼた。

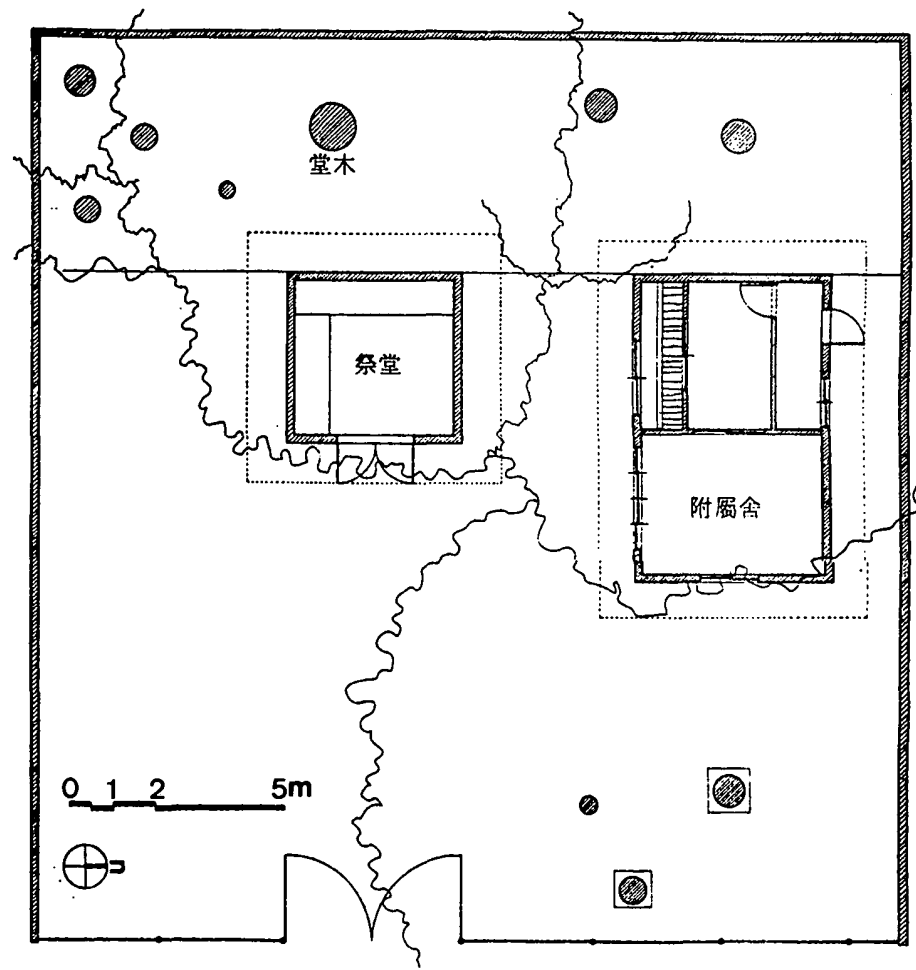

図 8 IV型祭祀空間（西生面鎮下集落）
(1)院集落（官営宿泊施設の集落）

国によってつくられた官営宿泊施設の集落には祭祀空閒が存在し ていない（温陽面院洞集落）。祭祀空間は集落民の安全と集落の内 外の秩序に関わる空間であることから普诵の集落に㤌存在していた。 しかしこのように宿泊を目的とする特別な集落には祭祀空間をつ くる必要がなかったものと考えられる。

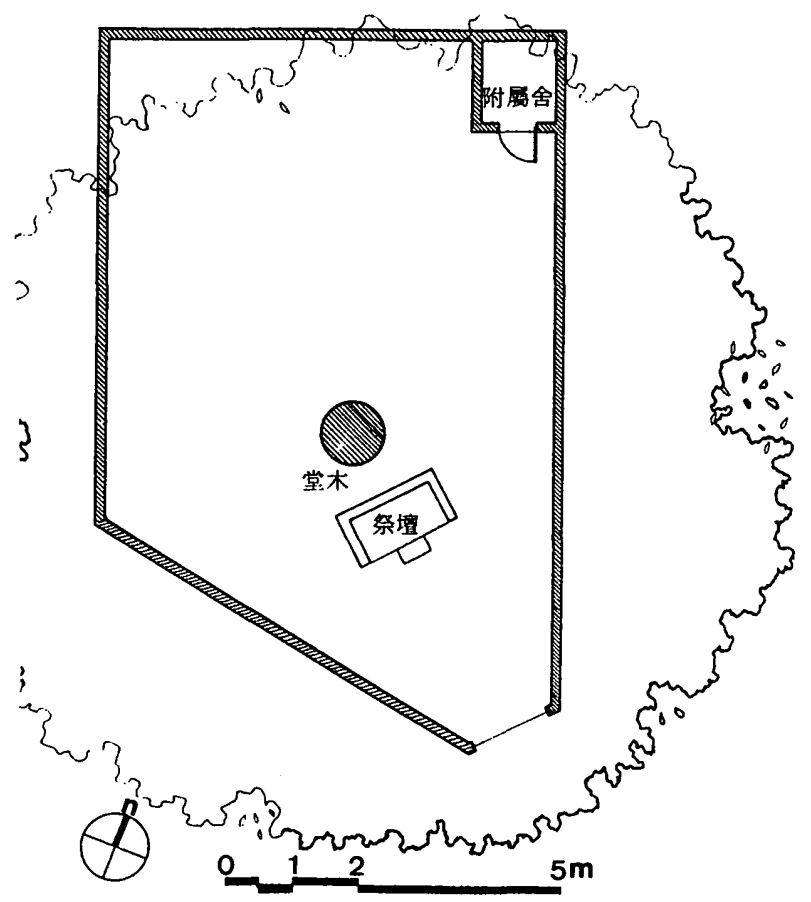

図 9 V型祭祀空間（斗西面大亭集落）

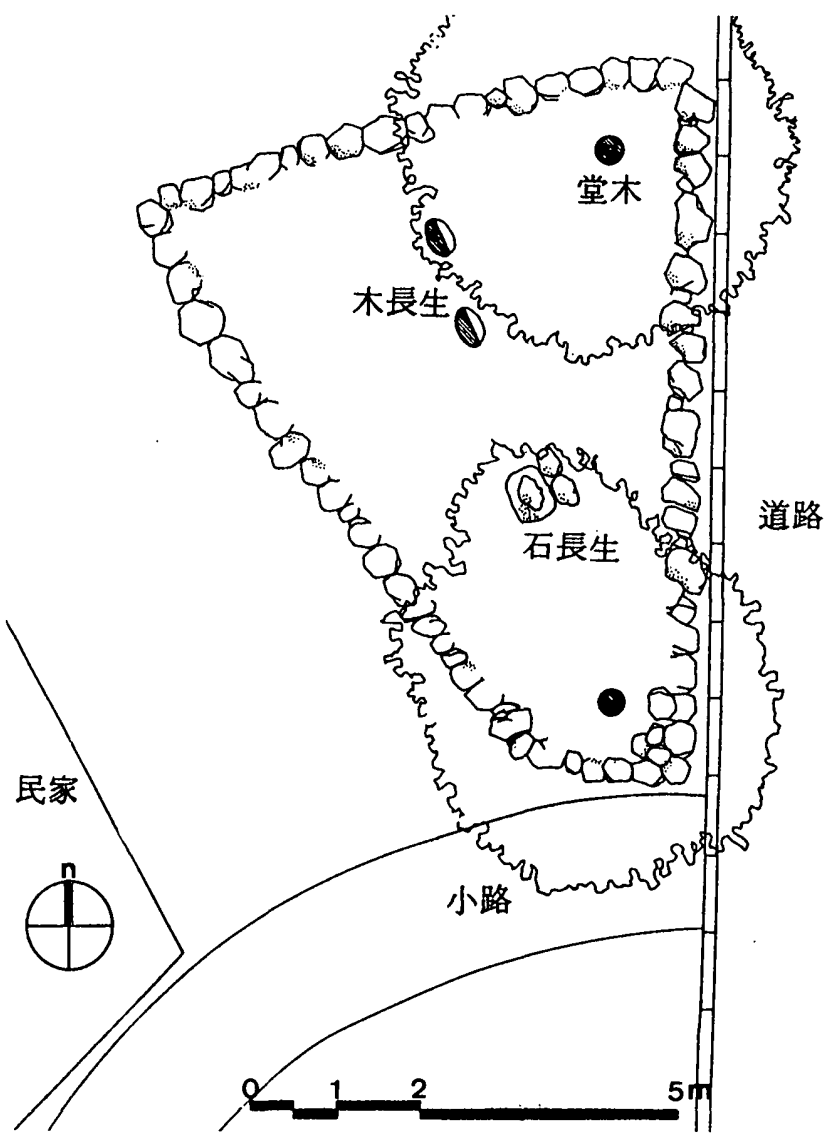

図 10 VI型祭祀空間（彦陽面東部里集落） 


\section{(2)市場集落}

集落全体が市場としてできたところには祭芜空間が存在していな い。昔ながらの市場は五日ごとに開かれ，売る人も買う人も近辺の 住民または市場ばかりを巡回寸る商人であることから祭祀空間はつ くらなかったものと思われる。その理由として考えられるのは近辺 の住民も商人も自分らの集落に祭祀空間を持っていたからである。 市場が開かれない日にちに市場村で暮らしている住民は宿泊施設ま たは酒屋を運営するわずかな人であった。そのような背景から生ま れた集落には今も祭祀空間はない。

(3)新しい集落

1945 年以降，1990 年以前に新しく開発された集落には祭 祀空間が存在しない。祭祀空間は住民自らが歷史とともに造り上げ てきたものであり，そこに属する集落住民は同質性をもつ特性があ る。しかし，国によって開発された集落に住んでいる集落民はその ような同質性を持ってない。また，開発した時に祭祀空閒用の敖地 が計画されなかったのも一つの理由になるものと思われる。

2) 祭祀空間が消滅した集落

調查集落 16 力所での祭祀空間の消隇の理由としては公共事業, 戦争、行政区域改編，自然災害，宗教などがあげられる。

\section{(1)公共事業}

公共事業は新しい村づくり運動であるセマウル運動と集落の集会 所建設とに大別できる。そのなかでもセマウル運動 ${ }^{24)}$ による祭祀 空間の消滅の例が 9 力所で最も多い。この運動の一環として行われ た集落道整備, 橋の建設などによって祭祀空間の敷地が犠牲になっ たのである。このように犠牲になった祭祀空間が位置していた敖地 は，公共敷地または河川敷地が多かった．そのため住民の意見など は通らず，祭祀空間がなくなったのである。このことは行政と住民 の祭祀空間に対する認識不足によるものと思われる。当時の政府は 古いものは良くないものであるという考え方を住民に押しつけ，伝 統性ある祭祀空間が消失されたと考えられる。また，近年になって， 祭祀空間がなくなった集落が 1 力所ある。1993 年に集落の集会 所であるマウル会館を建てるときであり、集落には堂木で構成され た祭祀空閒があったが，敷地確保のために祭祀空間をなくしたので ある ${ }^{25) 。}$

\section{(2)戦争}

戦争によるものとしては堂木の被害があげられる。例は多くない が朝鮮動乱の時に爆揧によって祭祀空間がなくなり，その後復元し ないまま今日に至っている例が 2 力所ある。

(3)行政区域改編

植民地時代に行われた行政区域改編の時には，規模が小さい集落 いくつかを一つの大きな集落にした結果，一つの集落に祭祀空間が 二つ以上になったが，近年にはこれと反対の動きもある。つまり、 大きい集落を二つに分けることによって祭祀空間の数を少なくした り、なくしたり例が 2 力所ある。

\section{(4) 自然災害}

自然災害による祭祀空閒の消失は台風によるものがほとんどであ る。この場合も堂木だけで構成されている祭视空間の被害例で、2 カ所ある。

(5)宗教

宗教によるものとしては，集落の住民にキリスト教を信じる信者
の数が増えたことで祭祀空閒をなくした例であり、1例ある。

6.まとめ

以上のことから本研究は次のようにまとめることができる。

（1）韓国の伝統的な農村集落, 特に蔚山郡の集落には住民の求心 点である祭祀空間が存在し，機能している。

（2）祭祀空間は，主に堂木，祭堂で構成されているが，それ以外 にも長生, 岩及び石積みもみられた。堂木は232 集落の261力 所でケヤキ，松，エノキなどの老巨樹で構成されていた。祭堂は 1 83 集落に2 10 力所でみられた. 祭堂の材料, 形式などは建て替 えの度に新しく変化し，集落による違いがみられる。

(3) 祭祀空間はその構成要素から6つのタイプに分類できた。そ の中，堂木及び堂木群で構成されているI型が $23 \%$, 堂木及び 堂木群・祭堂で構成されたII型が $63 \%$ あり，この 2 つのタイ゚ が蔚山地域の一般的な祭祀空間であることが分かった。

（4）その類型別の地域の特徽が見られた。とりわけ，地理的に都 市部に遠いほど祭祀空閒の原型が残されていた。このことは，祭祀 空間の原型であるI 型が都市部から離れ, 集落の変化も少ない地域 に最も多いことを意味する. また，堂木に祭堂が加わった II 型は都 市部に近い地域に普遍的に存在する分布の特徽がみられた。

（5）集落での祭祀空間の有無は集落の性格に大きく関倸している。 つまり，祭祀空間は調查地域の農村集落には一般的に存在していて， これがない集落とはその性格の差が大きい。祭祀空間の存在しない 集落としては院集落, 书場集落, 戦後の新しい集落などが確認でき た.

（6）祭祀空間の消减している例がわずかながらみられた. その理 由について考察した結果, 公共事業によるものが最も多くみられた. このことは行政の祭祀空間に対する認識不足をあらわしているもの と考えられる。

\section{注及び引用文献}

（1）韓国の集落には“洞祭”という村単位で行われる祭祀がある。この祭 祀は豊年と集落の安全，住民の健康などを目的として毎年陰曆 1 月 15 日に 行われる，祭祀恃供えものを住民が供え，祭祀空間でおじぎをした後，供え ものをみんなで食べながら交流を梁めるものである。祭祀の名称は地域によ って異なるが内容的な面では共通点が多い。

（2）農民がドレという生産共同体によって農作業をおこなう時の音楽であ る。広い意味ではケンガリ，ジン，ザング，太鼓などの打楽器を演奏しなが ら行進，侥式，労㗢をする音楽のことである。

（3）村山智順著，『朝鮮の部落祭』(朝鮮総督府，1937 年発行）

(4) 祭祀空間の構成要素。本文の祭祀空間の定義のところで説明した。

（5）祭祀等間に関する文献上の記録は三国史記, 三国遭事などの古文書に 見られるが，今日と同じものであるかどうかは分からない。そして祭视空間 に関する調查報告は植民地時代の文献が最初である。韓半島全地域の集落の 祭祀について調查した 1937 年朝鮮総督府発行の「朝鮮の部落祭」がそれ である。また，韓国全地域の農村を調查したのが1993 年日本建築学会大 丟で報告されている。斎木崇人，共生と現代一東アジア集住文化を通底する ものー「韓国の堂木と集落の空間構成」。しかし，韓国全地域の調査であり ながら集落の数は 131 力所に留まっている。

（6）韓国の行政区域は大きぐ都市と農村とに分ける。都市と農村を含む大 
きい単位として道があり，続いて都市部を市，区，洞に，農村部を郡，邑， 面，里，マウルに分類する。

（7）蔚山市は1995年に蔚山郡を蔚山市区域に併合し薡山通合市に昇格 した。そのことによって蔚山郡は蔚山市の一つの区すなわち，蔚州区人と行 政名が変わった。また, 蔚山市は1997年 7 月に蔚山広域市に昇格した。 このことによって蔚州区の一部地域は蔚山市の北区になり，残りは再び蔚州 郡上なった。しかし，このような行政名の变化は形としての閣題であり，そ の中の生活の変化はすぐに現れないものである。それで本研究では1994 年12月現在の名称を使うことにした。

（8）ダンスナムは, ダン (堂) +ス (楜) +十ム (木) のことである。韓 国の集落の入口または集落の中心部には大体大きな樹木があり，機能により ダンスナムとソンザナム (亭子木) に分けられる。榯木の日常的な利用は二 つ共に同じであるが，非日常的な利用によって区別できる。つまり，集落の 祭祀である洞祭を行うかどうかによる。祭祀を行う方がダンスナムであり， 行わない方がソンザナムである。

（9）ザンスン (長生) は木または石でできた柱模様の上の部分に神または 将軍の顔を彫り，下の部分には役割を示す文字を書いて道ばたにたてるもの である。

(10) ゼダン (祭堂) は洞祭をまつる場所である。祭堂にまつられた神の 性格によって山神堂, ソナン堂, ゴルメギ堂などに呼ばれるが調査地域では “祭堂”が一般的な名称である。

（1１）一つの集落に祭祀空間が二つ以上あるのが 30 事例があるため集落 の数と祭祀空間の数が異なる。また、堂木の所在する個所は表 2 の 型、II 型、IV型、V型の事例数とVI型の内、堂木のある6事例を合加せて 266 と する。

（1２）祭堂の建て替えは決まった期間または時期があるのではなく，集落 の財政が良くなり，祭堂がふるくなったら建て替えをするのである。全集落 に祭堂がある熊村面（22 集落に 24 の祭祀空間があり，その中で祭堂があ

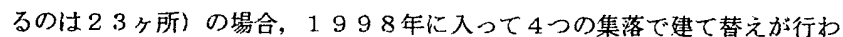
れた。建て替えの際に木構造が組積造に变わった。

（1３）韓国ではこのような塀にある門を大門と呼ぶ.

（14）面には生活基盤である5 日市場がひとつあり，面役場がある単位で あることから面に属している各々の集落住民の生活ぶりなどがよく似ている， （15）セマウル会館は集落の集会所であるが集落共同のものの収納空間上 しても利用されている。また，有司は集落の祭祀至担当する人のことであり， そのひとの家に祭祀用のものが収納されている場合もあるにのことについ ては別稿で論じる)

（1６）ソナンダンの分布を全国的にみると，堂木形態の次に多いのが石積 み，その次が石積み+堂木の形態である(文化財管理局，部落祭堂，196 9)。

(1 7)この調査は文化財管理局が1969年汇行ったものであるが，之和 によると, 震南の祭祀空間の分布は次の通りである。（文化財管理局, 全掲 㶳, P P. $18 \sim 28$ )

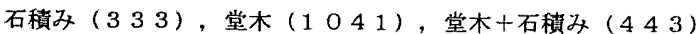

（1８）韓国の一番古い神話である壇君神話に神境榯という神木（堂木）が でてくる。塯君は韓国民族を創り出した人物であり，その時から神木信仰が あったと思われる。そのことから堂枕汁で構成さ机ている祭祀空間が原型 だと考えられる。

(19)この時の調查報告書は祭祀空間の数乞集落の数こついては書いてい ない。存在比率だけ書いてあるため，同し地域での調査であるが漏机があっ
たかどうかはかからない。調查漏れがなかったとすれば祭㒭空間はその後， 增えていると思われる。

(20) 韓国の集落の規模は10戸以内のものから200戸以上のものまで 様从であるが普通汢 50 ○留後が多い。規模が小さいとい5の时大凡 30 戸 以内であり，大きい規模というのは 100 戸以上である。

（21）「朝鮮の聚落の場所論的構造一河回マウルの場合一」，西垣 安比 古, 『年報朝鮮学』、1994 年

（２２）例えは祭祀空間が二つある石川マウルには石川と石渓というニつの 集落名がある。また四つある盤谷マウルには銀洞，高下，玉洞，真玄という 四つの集落名がある。

（2３）院集落々は高麗時代から強化された中央集権制度により，首都と地 方を結ぶ主要街道に沿って発達した宿泊と交通を中心にして形成された集落 のことである。とりわけ，駅に近接して位置し，共用旅行者の宿食提供と留 客の接待をする客舎中心の集落である。このような集落は近代に入って政治, 社会制度の変革拉よび交通革命で殆どなくなった。

(2 4) この運動は, 韓国の産業化が始まって間もない頃にあたる1970 年に始まった新しい村づくり運動である。

（2５）この集落では最初は堂木を移植するつもりであったが，敷地確保が 難しく, 移植ができないまま祭祀空間がなくなってしまった，調査の時，住 民の意見は敷地が確保できる次第祭祀架間をつくりたいとのことであった。

(1998年 9 月 9 日原稿受理，1999年 5 月24日採用決定) 